\title{
A rezgésdiagnosztika alkalmazása a magyar honvédség technikai kiszolgálása és jármüjavítása során - 2. rész
}

\author{
Application of Vibration Diagnostic Procedures in the \\ Technical Service and Maintenance System of the Hungarian \\ Defence Forces - Part 2
}

\begin{abstract}
A folyamatos technikai fejlödésének köszönhetően, a modern gépjármüvek felépitése egyre öszszetettebb a korábbi technikákhoz képest, és széles körben elterjedt a számítógépes, automatizált vezérlési rendszerek alkalmazása. Ennek következtében a karbantartási, javítási műveletek során már nem elég csupán a szubjektiv vizsgálatokra, ellenörzésekre hagyatkozni, hanem elengedhetetlenné vált a diagnosztikai vizsgálatok bevonása. A Magyar Honvédségállományába folyamatosan rendszeresitik az olyan számítógépes rendszerekkel rendelkező haditechnikai eszközöket, amelyek technikai kiszolgálása és javítása csak modern diagnosztikai eljárások alkalmazásával valósítható meg. Egy, a diagnosztikai vizsgálatok rendszeres alkalmazásán alapuló üzemfenntartási rendszer lényeges elönyökkel járhat, mivel biztositja a gyors és precíz munkavégzést. A rezgésdiagnosztika a gyakorlatban legtöbbet használt diagnosztikai vizsgálat, hiszen a gépek megbontása, roncsolása nélkül, csupán a gép által keltett rezgések alapján képes a gép alkatrészeinek müködés közbeni folyamatos ellenőrzésére, meghibásodása esetén a hiba helyének pontos behatárolására.
\end{abstract}

Kulcsszavak: diagnosztika, rezgésdiagnosztika, technikai kiszolgálás, javítás

The structure of the modern vehicles is more complex than before because of the continuous improvement of technics. The application of automatic computer control system is widespread. Consequently, the involvement of diagnostic procedures became necessary in maintenance and

Nemzeti Közszolgálati Egyetem Hadtudományi és Honvédtisztképző Kar, honvédtisztjelölt, e-mail: jusztin.karina@ gmail.com, ORCID: https://orcid.org/0000-0002-1999-4629

2 Nemzeti Közszolgálati Egyetem Hadtudományi és Honvédtisztképző Kar, egyetemi docens, e-mail: vegh.robert@ uni-nke.hu, ORCID: https://orcid.org/0000-0002-9786-6702 
repair operations, in subjective examinations and inspections. Military technology equipment with computer systems are continuously authorised at the Hungarian Defence Forces. The technical service and repair of these equipment is feasible with application of modern diagnostic procedures. A maintenance process based on regular usage of diagnostic procedures ensures advantages by quick and exact work methods. The vibration diagnostic is the most often used diagnostic inspection. According to the vibration of the equipment we are able to check the components and determine the exact location of the failure without any destruction.

Keywords: diagnostic, vibration diagnostic, technical service, repair

\section{A gépjármü-diagnosztika alkalmazása a Magyar Honvédségben}

A Magyar Honvédség (MH) üzemfenntartási rendszere sajátos, mivel a katonai alkalmazás speciális követelményeket támaszt a kiszolgálási rendszerrel szemben. Egy katonai feladat végrehajtására alkalmazott haditechnikai eszköz lényegesen eltér egy közúti közlekedésben vagy közúti áruszállításban használt jármütől, mivel a katonai gépjármüvek esetében elengedhetetlen feltétel, hogy rendelkezzenek olyan speciális műszaki paraméterekkel, amelyek képessé teszik azt a feladat végrehajtására. A katonai üzemfenntartás rendszerének vizsgálatakor figyelembe kell venni, hogy az üzemeltetés nem állandó intenzitású. A kiképzési, felkészülési időszakban az üzemeltetés igen alacsony mértékü, míg egy minősített helyzet esetében az üzemeltetés mértéke nagyságrendekkel megnőhet. Nehezíti a tervezés körülményét, hogy az üzemeltetés mennyiségi növekedése nem minden esetben jelezhető elöre. További speciális tényező, hogy egy honvédségi szervezet összetett járműparkkal rendelkezik, amelyet nagyszámú és sokféle típusú eszköz alkot. A katonai eszközök üzemfenntartásában tehát figyelembe kell venni, hogy a rendszernek képesnek kell lenni kielégíteni egy alacsony és egy magas intenzitású géphasználatot, illetve kezelnie kell azt a szituációt is, amikor egy adott időponttól és adott időintervallumra magasabb volumenü üzemeltetést kell kiszolgálni. ${ }^{3}$

A Magyar Honvédségben a páncélos- és gépjármütechnikai eszközök üzemben tartása jelenti az üzemeltetett (használt, alkalmazott) haditechnikai eszközök üzemképes állapotban tartását és adott feladatra alkalmazhatóságának növelését. Célja a katonai műveletek sikeres végrehajtásának biztosítása a technikai támogatás feladatain belül. Az üzemben tartás magában foglalja a technikai kiszolgálásokon túl a haditechnikai eszközök üzemeltetési körülményeinek, igénybevételi mutatóinak elemzését, a megfelelő technikai kiszolgálást, a harci alkalmazásra való felkészítést, valamint a megsérült és meghibásodott haditechnikai eszközök helyreállítását és visszatérítését.

Az üzembentartási folyamatnak számos funkciója van. Ezek közé tartozik a tervezés, az üzemeltetés (használat), a technikai kiszolgálás, karbantartás, a felkészítés harci alkalmazásra, a helyreállítás, a müszaki, hatósági vizsgálatok, a mérések és hitelesítések, a tárolás, a selejtezés,

Gyarmati József: Az üzemfenntartás speciális katonai követelményei. Haditechnika, 53. (2019), 4. 3-10.; Vég Róbert László: A közszolgálati feladatok ellátásához szükséges gépjármüvek technikai szintjének meghatározása. Bolyai Szemle, 26. (2017), 1. 18-19. 
az újrahasznosítás, a nyilvántartás és az elszámolás. Az MH technikai karbantartási rendszerében a szakképzett javító- és karbantartó-állomány szaktudása és alkalmazhatósága adja azt a képességet, amely az igénybevételre alkalmas technikai eszközök meglétét biztosítja. Az állomány feladata eddig főként a haditechnikai eszközök állapotmegóvásában, felkészítésében merült ki. Azonban olyan eszközökkel bővült a MH eszközparkja, amelyek javításikapacitás-igénye nemcsak kézi szerszámok alkalmazásában merül ki, hanem már korszerü diagnosztikai ismereteket is követel. A MH-ben alkalmazott Tervszerü Fenntartási Rendszer (TFR) valójában nem ad lehetőséget csak az állapot szerinti karbantartásra, mivel idő- és teljesítménynorma alapján írja elő a karbantartási feladatokat. Van lehetőség szükség szerinti javításra, ez a technikai kiszolgálások során és a használat közben jelentkező meghibásodások megszüntetésére szolgál. Mivel nincs lehetőség az eszközök valós használatához igazítani a technikai kiszolgálások végrehajtását, kissé elavult rendszernek minősül ebben a tekintetben. A korszerű eszközök fedélzeti diagnosztikai rendszerei lehetővé teszik a részegységek, fődarabok állapotának gyors felmérését, azonban számos olyan eszköz van a MH rendszerében, amely nem rendelkezik ilyen technológiával.

\subsection{A Magyar Honvédség Tervszerü Fenntartási Rendszere}

A MH Tervszerü Fenntartási Rendszere az állományába tartozó páncélos- és gépjármütechnikai eszközök technikai kiszolgálását a TFR keretein belül valósítja meg. A TFR magában foglalja a tervszerü, megelőző jelleggel végzett, valamint a szükség szerint végzendő technikai kiszolgálási és javítási feladatok összességét. Ezeket az üzemeltető alegységek, a páncélos- és gépjárműtechnikai szolgálatok szakjavítói, a központi javítószervek, polgári vállalatok által végzik. A TFR-rendszer hivatott biztosítani a $\mathrm{MH}$ rendszerében lévő páncélos- és gépjármütechnikai eszközök, anyagok folyamatos, megbízható üzemkészségét, készletteljességét, előírt állapotát, üzemeltetési tartalékát. A MH páncélos- és gépjármütechnikai eszközök tervszerű fenntartási rendszere 6 technikai kiszolgálási (TK) szintet (1. 2. 3. 4. 5. és 6. TK) foglal magában. Az első 4 fokozatba tartoznak a végrehajtás szintje és a müveletek mélysége szerint tagolt technikai kiszolgálások (1-4. TK), míg az 5. és 6 . technikai kiszolgálási fokozatot a tervszerü megelőző javítások alkotják. Az egyes fokozatok során végrehajtandó müveleteket és a rájuk vonatkozó követelményeket az eszközökhöz kiadott dokumentációk, karbantartási és javítási utasításaik tartalmazzák. A fokozatok mind egyike technologizált müveletek összességét foglalja magában, amelyeket a honvédségi szervezetnek vagy kijelölt javítószerveknek kell tervezni és végrehajtani. Az 1. és 2. TK-fokozatot az üzemeltető alegységek kezelő- és szakjavító állomány, a 3. és 4. TKfokozatot a kezelő személyek bevonásával a javító szervek szakállománynak kell végrehajtania, ugyanakkor a technikai kiszolgálások polgári szervektől is megrendelhetők a csapat-előirányzat terhére. A technikai kiszolgálási fokozatok esedékességét naptári időnorma, teljesítménynorma vagy a végrehajtandó feladat jellege alapján határozzák meg. A naptári időnorma a két technikai kiszolgálás között maximálisan megengedhető időtartamon alapul, míg a teljesítménynorma a két technikai kiszolgálás között teljesíthető, az eszköz használatára jellemző valamilyen paraméter (például kilométer, üzemóra, lövésszám), mennyiség. A végrehajtandó feladat miatt esedékes technikai kiszolgálást akkor hajtják végre, ha a technikai kiszolgálás valamelyik fokozatát a meghatározott technikai állapot elérése érdekében kell elvégezni az adott feladat előtt vagy 
után. A honvédségi szervezet a harckészültségi követelményei, kiképzési tervei, igénybevétel tervezett mértéke és a javító alegység kapacitásának figyelembevételével tervezi a páncélosés gépjármütechnikai eszközeinek technikai kiszolgálásait, ezért a foglalkozások, gyakorlatok tervét úgy kell elkészíteni, hogy mindig biztosítva legyen a szükséges idő az eszközök technikai kiszolgálására. ${ }^{4}$ Az alegységek számára biztosítottak úgynevezett technikai kiszolgáló napok, amelyek az esetleges feladathoz kötött technikai kiszolgálásokra, illetve a téli (október 1-31.) és nyári (április 1-30.) igénybevételre való felkészülésre használhatók fel. Minden páncélosés gépjárműtechnikai eszközzel végrehajtandó igénybevétel vagy foglalkozás előtt, valamint az igénybevétel közben az 1. TK-t, az igénybevételt követően a 2. TK-fokozatot kell elvégezni. ${ }^{5}$

\subsection{A Magyar Honvédségben alkalmazott gépjármüdiagnosztikai eljárások}

Ahogy a diagram (1. ábra) és különböző típusú járművek adatait mutató táblázat (1. táblázat) is mutatja, a TK-műveletek összességében csekély számú műszaki diagnosztikai vizsgálat jelenik meg. Az elvégzendő feladatok többségében a gépjárművezető vagy az adott javítási, ellenőrző munkálatot végző személy érzékeire vannak bízva.

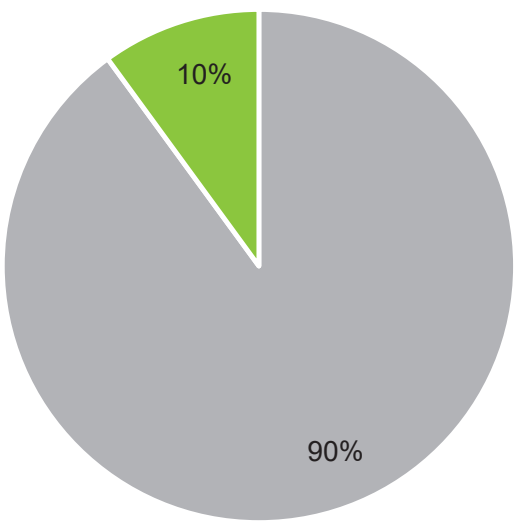

Szemrevételezéssel végzett feladatok (\%) Diagnosztikával végzett feladatok (\%)

1. ábra. A TK-feladatok megoszlása a diagnosztikai vizsgálatok alkalmazásának tekintetében

Forrás: a szerző saját szerkesztése az 1. táblázat adatai alapján

Összevetve az eddigiekben rendszeresített eszközöket azokkal a rendszerbe került eszközökkel, amelyek karbantartása és javítása már korszerü diagnosztikai méréseket követel, megvizsgálható a technológiai fejlődéssel járó szintemelkedés a technikai kiszolgálás feladataiban is. A változás mind az eszközökben, mind az eszközök vizsgálatához, állapotfelméréséhez, ellenőrzéséhez kapcsolódó eszközökben látható. Minden jármüre vonatkozóan különböző anyagismereti,

4 Kurcz Kristóf - Vég Róbert László - Hegedűs Ernő: A Leopard 2 harckocsicsalád és a Magyar Honvédség 2A4 és 2A7+ típusváltozatai I. rész. Haditechnika, 54. (2020), 5. 2-7.

5 Gjmü/2-Gépjármü-igénybevételi szabályzat. A Magyar Honvédség Kiadványa, 2015. V-1-V-4. 
igénybevételi és egyéb utasításokban meghatározták a technikai kiszolgálások során végzendő feladatok egyes lépéseit, illetve az azokat végző személyek kilétét, valamint hogy a járműveknek milyen müszaki követelményeknek kell eleget tennie. Ezek alapján jól összehasonlíthatók az egyes típusok a feladatok során alkalmazott müszeres diagnosztika alkalmazását illetően. Az alábbi táblázatban különböző típusú, a MH állományában jelenleg is rendszerben lévő gépjárműveket hasonlítottam össze. Az UAZ-469B és a Mercedes Benz (MB) G-270 CDI járművek egyaránt terepjáró személygépkocsik, míg a Rába H-családba tartozó H14, a H18 és a H25 típusú járművek a terepjáró tehergépkocsik közé sorolhatók. Az UAZ-469B orosz gyártmányú terepjáró gépkocsit az 1970-es években rendszeresítették, alkalmazása sokrétű, alkalmas személyek és rakomány szállítására mind közúton, mind terepen és ezzel egyidejüleg egytengelyű rakományt is vontathat. A MB G-270 CDI-t a 2000-es évek ejelén rendszeresítették, alkalmazható személyek, illetve rakomány szállítására közúton és terepen egyaránt, típusváltozatait a $\mathrm{MH}$ különböző alakulatainál is alkalmazni tudják (például felderítők, egészségügy). A Rába H14, H18, illetve H25 típusú tehergépkocsik magyar gyártmányú, nagy teherbíró, széles körben, közúton és terepen egyaránt alkalmazható terepjáró haditechnikai eszközök. ${ }^{6}$

1. táblázat. A TK-műveletek megoszlása az egyes járművekre vonatkozóan

\begin{tabular}{|c|c|c|c|c|}
\hline \multicolumn{5}{|c|}{ UAZ-469B ${ }^{7}$} \\
\hline & 1. TK & 2. TK & 3. TK & 4. TK \\
\hline TK-feladatok száma (db) & 25 & 25 & 66 & 20 \\
\hline Szemrevételezéssel végzett feladatok száma (db) & 25 & 24 & 57 & 16 \\
\hline Diagnosztikával végzett feladatok száma (db) & 0 & 1 & 9 & 4 \\
\hline \multicolumn{5}{|c|}{ MB G-270 CDI ${ }^{8}$} \\
\hline & 1. TK & 2. TK & 3. TK & 4. TK \\
\hline TK-feladatok száma (db) & 26 & 31 & 17 & 16 \\
\hline Szemrevételezéssel végzett feladatok száma (db) & 25 & 30 & 14 & 14 \\
\hline Diagnosztikával végzett feladatok száma (db) & 1 & 1 & 3 & 2 \\
\hline \multicolumn{5}{|c|}{ Rába H14 ${ }^{9}$} \\
\hline & 1. TK & 2. TK & 3. TK & 4. TK \\
\hline TK-feladatok száma (db) & 47 & 48 & 21 & 7 \\
\hline Szemrevételezéssel végzett feladatok száma (db) & 47 & 43 & 18 & 2 \\
\hline Diagnosztikával végzett feladatok száma (db) & 0 & 5 & 3 & 5 \\
\hline
\end{tabular}

6 Vég Róbert László: A műszaki diagnosztika szerepe a technikai kiszolgálási és járműjavítási tevékenységben. Hadmérnök, 9. (2016), 2. 1-9.; Vég Róbert László: Logisztikai szaktechnikai eszközök I. Budapest, Dialóg Campus, 2018. 12-58.

7 Gjmü/126. Az UAZ-469B típusú terepjáró személygépkocsi anyagismereti és igénybevételi utasitása. Budapest, Honvédelmi Minisztérium, 1976. 341-357.

8 Utasítás a MB G-270 CDI BA 4, BA6/PK, BA10/F típusú terepjáró személygépkocsik karbantartásához és technikai kiszolgálásához. Budapest, Magyar Honvédség Szárazföldi Parancsnokság Logisztikai Főnökség. 2005. 3-8.

9 Utasítás a RÁBA H14 típusú terepjáró tehergépkocsi karbantartásához és technikai kiszolgálásához. Budapest, MH Páncélos- és Gépjármütechnikai Szolgálatfőnökség, 2005. 3-10. 
Jusztin Karina Zelma - Vég Róbert László: A rezgésdiagnosztika alkalmazása a magyar honvédség technikai kiszolgálása...

\begin{tabular}{|c|c|c|c|c|}
\hline \multicolumn{5}{|c|}{ Rába H18 ${ }^{10}$} \\
\hline & 1. TK & 2. TK & 3. TK & 4. TK \\
\hline TK-feladatok száma (db) & 44 & 47 & 22 & 8 \\
\hline Szemrevételezéssel végzett feladatok száma (db) & 44 & 43 & 19 & 3 \\
\hline Diagnosztikával végzett feladatok száma (db) & 0 & 4 & 3 & 5 \\
\hline \multicolumn{5}{|c|}{ Rába H25 ${ }^{11}$} \\
\hline & 1. TK & 2. TK & 3. TK & 4. TK \\
\hline TK-feladatok száma (db) & 42 & 46 & 22 & 8 \\
\hline Szemrevételezéssel végzett feladatok száma (db) & 42 & 41 & 19 & 3 \\
\hline Diagnosztikával végzett feladatok száma (db) & 0 & 5 & 3 & 5 \\
\hline
\end{tabular}

Forrás: a szerző szerkesztése

Az 1. táblázat adataiból látható, hogy egy régebbi típusú jármü - például az UAZ-469B - és egy viszonylag újonnan rendszerbe került, jóval fejlettebb technológiai szinttel rendelkező eszköz - például a MB G-70 CDI vagy a RÁBA H család - 1. és 2. TK műveletei során nem nőtt jelentős mértékben a diagnosztikával végzett vizsgálatok száma. Nem meglepő, mert a legtöbb elvégzendő feladat a feladatot elvégző személy, jelen esetben a gépjárművezető érzékszerveire van bízva, hiszen ő nem rendelkezik megfelelő mérőeszközökkel és a mérések, vizsgálatok elvégzésére sem biztosítottak az egyéb feltételek.

A 3. és 4. TK feladatai között az UAZ-469B jármű esetében már megjelennek konkrét diagnosztikai feladatok, mint például a kerékösszetartás, fékberendezés ellenőrzése, vagy a fényszórók beállítása, annak ellenőrzése. Az MB G-270 CDI terepjáró személygépkocsi egy következő technológiai fejlettségi szintet képvisel, mivel ez a jármű képes öndiagnosztikát végrehajtani. A jármüre vonatkozó 3. és 4. TK-műveletek közt új vizsgálatok is helyet kapnak, mint például a motordiagnosztika, a fékrendszer fékpadon való ellenőrzése és a kormánygeometria ellenőrzése. A Rába H14, H18 és H25 terepjáró tehergépkocsik technikai kiszolgálási műveletei között nincs lényeges eltérés. Az 1. TK mindhárom eszköz esetében egyáltalán nem tartalmaz diagnosztikai műszerrel végzett vizsgálatot. A 2. TK során a motor működésének diagnosztikai műszerrel való ellenőrzésre, hibakód-kiolvasásra, szelephézag-beállítás, futómű-beállítás, fékrendszer műszeres ellenőrzésére kerül sor. A 3. és 4. TK is viszonylag kevés diagnosztikai müszerrel végrehajtott vizsgálatot követel. A 3. TK elvégzése alatt, a diagnosztikai müszerekkel végzett vizsgálatok tekintetében a járművek a motor működésének diagnosztikai műszerrel való ellenőrzésén, az esetleges hibakódok kiolvasásán, a fényszórók beállításának ellenőrzésén, valamint az akkumulátorok töltöttségének műszeres ellenőrzésén esnek át. A 4. TK műveletei kiegészülnek még a kormánygeometria és futómü beállítottságának vizsgálatával, valamint a fékrendszer próbapadon való ellenőrzésével.

Összegezve a fentieket elmondhatjuk, hogy az egyre magasabb technikai fejlettségi szintet képviselő haditechnikai eszközök MH-ben való megjelenése, rendszeresítése, alkalmazása ellenére sem válnak elterjedtebbé a nagyobb pontosságot és gyorsaságot nyújtó diagnosztikai müszerrel végzett vizsgálatok.

10 Utasítás a RÁBA H18 típusú terepjáró tehergépkocsi karbantartásához és technikai kiszolgálásához. Budapest, MH Páncélos- és Gépjárműtechnikai Szolgálatfőnökség Kiadványa, 2005. 3-10.

11 Utasitás a RÁBA H25.206 típusú terepjáró tehergépkocsik karbantartásához és technikai kiszolgálásához. Budapest, MH Páncélos- és Gépjármütechnikai Szolgálatfőnökség Kiadványa, 2005. 3-10. 


\section{Következtetések}

A Magyar Honvédség Tervszerü Fenntartási Rendszere a megelőző jelleggel végzett technikai kiszolgálási és javítási feladatok összességével hivatott biztosítani a páncélos- és gépjármütechnikai eszközök folyamatos és megbízható üzemkészségét, készletteljességét, előírt technikai állapotát és üzemeltetési tartalékát. A TFR hat fokozata közül a jelenlegi rendszerben az 1. TK nem, a 2., 3. és 4. TK pedig közel arányos mértékben tartalmaz diagnosztikai műszerrel végzett vizsgálatot. A rezgésdiagnosztikai müszerrel végzett vizsgálatokat a 3. és 4. TK, illetve 5 . és 6 . TK során lenne célszerű alkalmazni. Az 1. és 2 . TK-t a gépjármű vezetője végzi, azonban a rezgésdiagnosztikai vizsgálatok nagy szakértelmet és képzett szakembert követelnek meg, az értékes müszereket pedig szakavatott szerelők kezelik, ami nem várható el a gépjárművezetőktől. A 3. és 4. TK során a kezelők bevonásával a szakjavítók végzik el az előírt technikai kiszolgálási lépéseket. Ezeken a szinteken már hatalmas elörelépést jelentene a rezgésdiagnosztikai vizsgálatok alkalmazása, akár a páncélos- és gépjármütechnikai eszközök meghibásodásakor a hiba pontos helyének és okának megállapítására, akár a javítás során ellenőrzésre, beszabályozásra, hiszen az eszköz javítómühelyben töltött ideje a mostaninál lényegesebben lerövidülne, az elvégzett munkálatok pedig a tényleges hibát szüntetnék meg. Az 5. TK során a gépjárművek részegységeinek, alkatrészeinek javítása, beszabályozása zajlik annak érdekében, hogy a 6. TK elvégzéséig még megfelelően tudjon üzemelni. Az eszköz új állapotát megközelítő teljes felújítása, alkatrészek cseréje, beszabályozása a 6 . TK végrehajtásával valósul meg. Korszerű rezgésdiagnosztikai müszerekkel nemcsak a technikai kiszolgálás legidőigényesebb szintje rövidülne le lényegesen, hanem biztosabb és megbízhatóbb beszabályozások elvégzésével csökken a hirtelen meghibásodások kockázata.

Összességében tehát a gépjármü-diagnosztika, kiemeltképp a rezgésdiagnosztika, alkalmazása kétségkívül előnyös lenne a Magyar Honvédség technikai kiszolgálási és javítási rendszerében, hiszen a páncélos- és gépjármütechnikai eszközök géphiba miatti üzemképtelensége és állásideje lényegesen lerövidülne, valamint a gép hibáiból eredő költségek is jelentősen csökkenthetők lennének.

\section{Felhasznált irodalom}

Gjmü/126. Az UAZ-469B típusú terepjáró személygépkocsi anyagismereti és igénybevételi utasítása.

Budapest, Honvédelmi Minisztérium, 1976.

Gjmü/2- Gépjármü-igénybevételi szabályzat. A Magyar Honvédség Kiadványa, 2015.

Gyarmati József: Az üzemfenntartás speciális katonai követelményei. Haditechnika, 53. (2019), 4. 3-10. Online: https://doi.org/10.23713/HT.53.4.01

Kurcz Kristóf - Vég Róbert László - Hegedűs Ernő: A Leopard 2 harckocsicsalád és a Magyar Honvédség 2A4 és 2A7+ típusváltozatai I. rész. Haditechnika, 54. (2020), 5. 2-7. Online: https://doi. org/10.23713/HT.54.5.01

Rahne, Eric: Üzemfenntartási tevékenységek. Online: https://docplayer.hu/17113474-Uzemfenntartasi-tevekenysegek.html 
Utasitás a MB G-270 CDI BA 4, BA6/PK, BA10/F típusú terepjáró személygépkocsik karbantartásához és technikai kiszolgálásához. Budapest, Magyar Honvédség Szárazföldi Parancsnokság Logisztikai Főnökség. 2005.

Utasítás a RÁBA H14 típusú terepjáró tehergépkocsi karbantartásához és technikai kiszolgálásához. Budapest, MH Páncélos- és Gépjármütechnikai Szolgálatfönökség, 2005.

Utasítás a RÁBA H18 típusú terepjáró tehergépkocsi karbantartásához és technikai kiszolgálásához. Budapest, MH Páncélos- és Gépjármütechnikai Szolgálatfönökség, 2005.

Utasitás a RÁBA H25.206 típusú terepjáró tehergépkocsik karbantartásához és technikai kiszolgálásához. Budapest, MH Páncélos- és Gépjármütechnikai Szolgálatfőnökség, 2005.

Vég Róbert László: A műszaki diagnosztika szerepe a technikai kiszolgálási és jármüjavítási tevékenységben. Hadmérnök, 9. (2016), 2. 1-9.

Vég Róbert László: A közszolgálati feladatok ellátásához szükséges gépjármüvek technikai szintjének meghatározása. Bolyai Szemle, 26. (2017), 1. 18-32.

Vég Róbert László: Logisztikai szaktechnikai eszközök I. Budapest, Dialóg Campus, 2018. 